\title{
8 Metaphor by any other name. A cognitive linguistic reassessment of Aristotle's theory of metaphor
}

\author{
pántes gàr hoi metaphérontes katá tina homoiótēta metaphérousin \\ 'For everyone who uses words metaphorically does so based on some sort of \\ likeness'. \\ - Arist. Top. $140 \mathrm{a} 11^{32}$
}

\begin{abstract}
Aristotle, according to the dominant view in the field of cognitive linguistics, is the father of an old, defunct and now refuted "classical" theory of metaphor based on literal similarity. But is the theory of metaphor put forward by Aristotle really so antithetical to the contemporary theory of metaphor in cognitive linguistics? Scholars in and out of this field have begun to question this depiction. In this paper, I take advantage of the very tools afforded by cognitive linguistics to reinterpret Aristotle's theory of metaphor. I argue that Aristotle has been misrepresented and suggest an alternate view which will be of interest to philosophers, philologists and cognitive linguists alike.
\end{abstract}

Keywords: Aristotle, metaphorá, metaphor, conceptual metaphor, cognitive linguistics, embodiment, construction, source frame, target frame, ónoma

\subsection{Introduction}

"Aristotle, the father of the traditional theory, was a literalist" who "was mistaken about metaphorical language being only poetic and rhetorical in nature and not part of ordinary everyday language”. With these words, Lakoff \& Johnson (1999), in staking out their contemporary theory of metaphor, have pigeon-holed Aristotle. This statement sums up the now-standard approach to Aristotle among cognitive linguists, setting him up as a sort of strawman representative of the "classical" theory - that metaphors are predicated on literal similarities between tenor and vehicle - against which the embodied approach is then positioned. In fact, the cognitive psychologist Eleanor Rosch, whose work has been foundational for cognitive linguistics, declared that:

32 All translations, unless otherwise noted, are the author's own. 
Prior to my work, categories and concepts were simply assumed, from philosophy, to be something explicit and formal, that is, to be arbitrary logical sets with defining features and clear-cut boundaries. This is what is now called the classical view of categories, which comes down from Aristotle through Locke and the British empiricists (Rosch, 1999). ${ }^{33}$

The Lakovian view has become almost reflexive, and it is probably fair to say that today a majority of cognitive linguists believe that since the mid-1970s the "classical" Aristotelian theory has been proven wrong - and that a window has opened for an empirically sound theory of categorization and metaphor. ${ }^{34}$ These conclusions are hardly surprising, inasmuch as they reflect the way Aristotelian scholarship has understood Aristotle's theory of metaphor even up to the present day. For instance, two recent studies still conclude that Aristotle used metaphor to "uncover similarities between entities in the world" (Marcos, 1997) or to reveal things that "bear some perceptible similarity to one another" (Wood, 2015).

A minority in the cognitive sciences, however, has attempted seriously to reconcile Aristotle's thinking on such topics as categorization, polysemy, definition and metaphor. As early as 1984, Swiggers (1984) argued that "one must take into account that it was Aristotle's intention to understand metaphorical communication within its broader cognitive and even ontological context”. More recently, Geeraerts (2006) has suggested that "the views of Aristotle also contain features that correspond rather with a cognitive than with a 'classical' approach" (see also Crittenden, 2003; Marcos, 1997; Wood, 2015). The traditional view of Aristotle has even been questioned among classical scholars too. The Aristotelian scholar Debora Modrak (2001) has recognized in her study of Aristotle's theory of language and meaning that "Under the influence of the much later Cartesian tradition, philosophers have too quickly found in Aristotle notions that are alien to his epistemology". Nevertheless, such attempts at recuperation among cognitive linguists have neglected to take full advantage of the available theoretical apparatus from cognitive linguistics itself. Instead of merely poking holes in the dominant view of Aristotle as the father of an old and nowdefunct system, a more fruitful approach may be to try to appreciate Aristotle's views of metaphor by using the very tools afforded by cognitive linguistics.

For this reason, by making full use of this theoretical apparatus, I am presenting a reassessment of Aristotle's views of metaphor which should prove to be useful to philologists, philosophers and cognitive linguists alike by (1) demonstrating the analytic potential of cognitive linguistics for the interpretation of ancient texts; (2)

33 Sullivan, 2013 has recently declared, "Aristotle presents metaphor as a linguistic ornamentation akin to the use of foreign words in a text, not as a way of thinking or a cognitive strategy. It is only relatively recently that metaphor has been reinterpreted as primarily a cognitive process that surfaces in language, rather than a rhetorical strategy that exists only at the level of language itself".

34 Taylor, 2003 outlines what he calls the "Aristotelian" theory touted as the basis for "mainstream twentieth-century linguistics”. 
allowing cognitive linguistics to answer the question of "what" Aristotle represents to it, in its own terms.

\subsection{The embodied basis of constructions and metaphor}

One of the defining terms of this volume is embodiment. Embodiment, the involvement of our human bodies in the physical world, is considered in cognitive linguistics to be the basis of our ability as humans to think (Lakoff \& Johnson, 1999). Another is construction, which I take to be equivalent to grammatical construction. According to Lakoff (1987), a construction is understood as "a form-meaning pair (F, M), where $\mathrm{F}$ is a set of conditions on syntactic and phonological form and $\mathrm{M}$ is a set of conditions on meaning and use". Constructions are formed at various levels of complexity and abstraction. They range from prefixes and suffixes to complex syntactic constructions such as the passive (Goldberg, 2013). Once learned, a construction (F) when uttered, evokes a meaning (M) in the mind. However, the meaning that is evoked is not singular, but a conceptual complex called a semantic frame. It is within a semantic frame that constructions gain meaning (Goldberg, 2010; Ziem, 2014). There is a similar phenomenon in listening to musical pitches. When one strikes the middle 'c' key on the piano, one does not hear a single pitch MIDDLE C, but a series of 16 different pitches, called overtones. MIDDLE $\mathrm{C}$ is heard as the dominant pitch within the 16. Just as MIDDLE C only gains recognition within this series of overtones, so also a construction $(F)$ only gains meaning $(M)$ within a semantic frame.

Semantic frames are idealized cognitive models of our embodied involvements, and are individually formed from repeated participation in specific cultural events. For example, the verb pay, when uttered, evokes the semantic frame COMMERCIAL TRANSACTION. This event contains a series of participants and objects: buyer, seller, goods, money, and so on. And just as when one strikes the middle ' $\mathrm{C}$ ' key on a piano and hears MIDDLE $\mathrm{C}$ as the dominant pitch of the series, so also when one utters (F) pay, the meaning (M) PAY becomes salient within the semantic frame COMMERCIAL TRANSACTION.

A third term that plays the pivotal role in this study is metaphor. In cognitive linguistics, there are (at least) two types of metaphor: a conceptual metaphor and an image metaphor. Both types of metaphor take the basic form: 'TARGET IS SOURCE'. In a conceptual metaphor, semantic frames play an important role in the transference of meaning from the SOURCE to the TARGET, because it is the inferential structure of the source frame that is transferred to and gives structure to the target frame. ${ }^{35}$ The transfer of inferential structure from the source frame to the target frame is called

35 Dancygier \& Sweetser, 2014 suggest using the terminology "source frame" and "target frame”, rather than "source domain" and "target domain". 
mapping. Generally, the transference of meaning is from a souRCE that is concrete and tangible, an experience we share with others, to a TARGET that is abstract, something we understand in terms of our embodied experience of a souRcE. The mapping is asymmetrical. As Sullivan (2013) puts it, a conceptual metaphor is “a cognitive process that allows one domain of experience, the target domain, to be reasoned about in terms of another, the source domain". A famous example is 'ARGUMENT IS WAR', wherein we view the abstract target, ARGUMENT in terms of the semantic frame of the concrete source WAR. As a result, we create constructions like, 'They shot down all my arguments', or 'I defended my argument', ${ }^{36}$ by employing terminology from wAR to shape the way we understand and talk about the event of ARGUING (see Dancygier \& Sweetser, 2014). An image metaphor is instead a transference between two domains of sensory experience without necessarily involving a mapping of inferential structure: e.g., an hourglass figure or a sweet voice. ${ }^{37}$

In this chapter, I interpret the embodied basis of grammatical constructions for an analysis of the semantic frames and metaphors in the ancient Greek of Aristotle. My goal is to invite the re-reading of Aristotle's texts in order to bring attention to what Aristotle had to say about metaphor. A comparison is helpful in illustrating why this is important. It is physically evident that sites of ancient Greek city-states have been destroyed or covered over by nature or man. With tools of greater precision being developed and used by archaeologists, these ancient sites are being more carefully uncovered, surveyed, analyzed and understood in an effort to reconstruct them (Trigger, 1996). Likewise, the thought of Aristotle has been distorted or covered over by anachronisms we inherit from received tradition. A glaring example of an anachronism, one that I take up in detail later in the present study, is that of the literal/metaphorical dichotomy imported into a reading of Aristotle in order to make sense of his theory of metaphor. The usual method is to translate into ancient Greek "literal" and "metaphorical". This method of "translating into" is a backward and anachronistic approach to the problem and adds to the distorted picture. However, with the advancements in the understanding of human language brought about by cognitive science, more precise tools are at the disposal of the philologist and philosopher for taking on the task of reconstructing the ancient Greek frames and metaphors that founded Aristotle's theory of metaphor. Thus, instead of putting words into Aristotle's words, instead of trying to reconcile his view, as I intend to demonstrate, the reader will be in a better position to allow Aristotle to speak.

In what follows, I present a reconstruction of Aristotle's theory of metaphor as it pertains to everyday (non-poetic) language use and point out what, I argue, has been

36 Googling these sentences, or ones like them, will reveal how pervasive this conceptual metaphor is.

37 The metaphor is not used in a reasoning process. For a recent and comprehensive discussion of metaphor in cognitive linguistics see Dancygier \& Sweetser, 2014. 
largely misconstrued. Although we lack a treatise in which Aristotle directly discusses metaphor in everyday language, there exist writings outside of Poetics and Rhetoric in which he uses the term metaphorá 'metaphor' or its verbal form metaphérein 'to transfer'. These texts are useful for gaining a broader understanding of his view of metaphor. The approach I adopt in examining these texts could be compared to the study of how a famous chef uses a cutting knife. Though this chef may not have produced a video that directly demonstrates the use of such a knife, one can systematize her technique by viewing videos wherein she uses a cutting knife in the preparations of various foods. Likewise, I systematize Aristotle's theory of metaphor for everyday language use based on his use of the term metaphorá in such texts.

I begin with his discussion of metaphor in Poetics and Rhetoric from which I reconstruct the source frame, namely, the transference of physical objects from one location to another, within which the term metaphorá gains meaning and examine the inferences which structure the metaphorical use of metaphorá in the target frame of lógos. From Aristotle's discussion, in these two texts, it will become clear that the metaphorical use of metaphorá is embedded in a larger conceptual metaphor of word use which is based in the intersubjective embodied experience of dwelling in the city-state (pólis), and the household (oîkos). 'DWELLING IN THE HOUSEHOLD' is the source frame which Aristotle uses to give structure to the target frame, 'THE LEXIS OF EVERYDAY LOGOS'. In addition to the term metaphorá there are three other terms that are central to this source frame: kúrion, allótrion, and oikeîon (these will be translated in the relevant sections). Aristotle has chosen terms that, as an ensemble, evoke the intersubjective embodied experience of living in a community and family. These terms each specify a certain role played by individuals in a hierarchical organization and are mapped onto and give structure to the three types of word use that, according to Aristotle, occur in the everyday use of language.

The larger conceptual metaphor that I will be arguing for, of which metaphorá is only a part, is diagrammed in Figure 1 below. For ease of explanation, I will be using the experience of dwelling in the household as the model. In the diagram, the inferential structure of the source frame 'DWELLING IN THE HOUSEHOLD' is shown mapping onto and giving structure to the target frame 'THE LEXIS OF EVERYDAY LOGOS'. The diagram outlines my argument and can be a useful reference throughout the article. The Greek terms will be fully defined in what follows. 


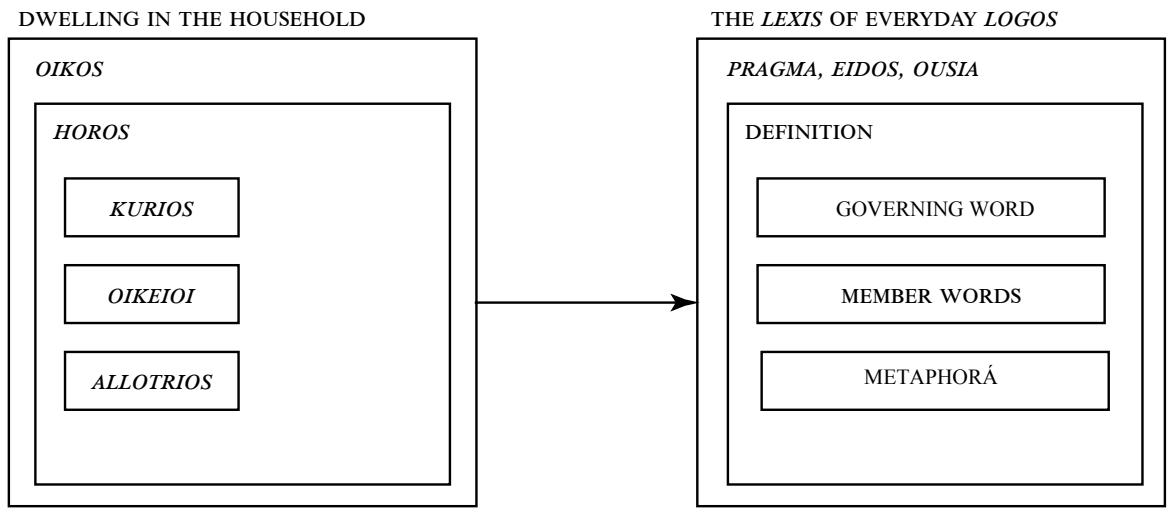

Figure 8.1: Metaphorical mappings in Aristotle’s metaphor of metaphorá.

I then proceed to Aristotle's usage of the term metaphorá in texts outside of Poetics and Rhetoric. In this regard, I consider a number of related texts, the most important of which are Aristotle's analysis of power (dúnamis) found in the Metaphysics Delta 1019a15-1020a6 and Theta 1046a4-1046b7, and his discussion of likeness (homoiotês) in Eudemian Ethics (EE, 1222b16-42). Though metaphor itself is not the topic of discussion, the use of this term in these assorted texts clarify where metaphor falls within Aristotle's theory of language. It is in his discussion of the meaning of the term dúnamis that it becomes clear what the kúrion use of a word means in contrast to its metaphorical use. The discussion in the Eudemian Ethics gives us a view of what Aristotle means by homoiotês with regard to metaphor.

Based on this analysis, I will demonstrate that: (1) Aristotle recognized metaphor as more than a literary device on the level of language, and not only included it in everyday language use, but also sanctioned its use in rhetoric upon the fact that metaphor is a part of everyday language; (2) Aristotle himself used metaphor as a part of his philosophical discourse, and he, in fact, elaborated his description of metaphor in metaphorical terms; (3) there is no literal/metaphorical dichotomy in his theory of metaphor, only the kúrion/metaphorical. The kúrion use of a word is itself polysemous; (4) he understood likeness in metaphor not only as a correspondence of literal properties but also as a kind of asymmetrical conceptual mapping, akin to conceptual metaphor.

\subsection{Aristotle's metaphor of metaphorá}

Of all those animals that form communities, Aristotle says that the human animal (zôion) is a political animal (politikón zôion) to the greatest degree, because humans alone possess lógos, i.e., the ability to deliberate and speak about these deliberations 
with oneself and with one another. As opposed to the mere voice with which other political animals, such as bees, signify the mere pleasant and the harmful, outside of any moral implications, it is the logos that makes known to the human community the perception of what is moral. The sharing (koinonia) of these moral precepts through lógos creates the household (oikía) and the city-state (pólis) (Arist. Pol. 1253a10ff).

We have in our possession two treatises of Aristotle entitled Poetics and Rhetoric in which he discusses the different ways this logos is expressed in the form of words (onómata). Aristotle used the metaphor of seasoned and unseasoned food to describe the use of words. Poetics includes a discussion of what Aristotle called "seasoned lógos” (hēdusménon lógon). By this he means poetic lógos, and he describes it as, "Lógos that has rhythm, harmony and melody" (Arist. Poetics, 1409b29). Rhetoric is a discussion of 'unseasoned' (psilós) lógos, by which he means lógos lacking rhythm, harmony and melody (Arist. Rh.1404b32-33). Aristotle used the term léxis to signify one's style of expressing lógos (Arist. Poetics 1450b14).

In both these treatises Aristotle discusses at length how metaphor fits into both the léxis of poetry and rhetoric. In Poetics, he describes how the poets form and use metaphors, along with many other word uses (Arist. 1457b1ff); in Rhetoric he prescribes how a public speaker should form and use metaphors. At the outset of the discussion of metaphor in Rhetoric, Aristotle makes a comment worthy of note, in which he identifies what sort of word use he recommends for the léxis of rhetoric. This statement clearly answers the question of whether or not Aristotle recognized metaphor as an occurrence in everyday, ordinary language:

tò dè kúrion kaì tò oikeîon kaì metaphorà móna khrếsima pròs tèn tôn psilôn lógōn léxin. sēmeîon d' hóti toútois mónois pántes khrôntai: pántes gàr metaphorâîs dialégontai kaì toîs oikeíois kaì toîs kuriois. (Arist. Rh. 1404b32-34))

'Only [words that are] kúrion and oikeîon, and metaphor, are useful for the léxis of the unseasoned (psilós) lógos. The reason for this is that everyone, while in conversation, uses [words that are] kúria and oikeîa and metaphors'.

Contrary to the received tradition that Aristotle only saw metaphor as a poetic and rhetorical device, I argue that he not only places the use of metaphors in the léxis of everyday lógos, but he also considers the use of metaphor in rhetoric to be derived from and sanctioned by its everyday use. The rhetorician is to mimic the plain, unseasoned ( $p$ silós) everyday use of lógos, by using words that are metaphorical, kúria and oikeîa.

From this text in Rhetoric, it becomes clear that Aristotle not only used the form (F) metaphorá, but also used the two forms, kúrion and oikeîon, to define the léxis of everyday lógos. But what do these forms (F) mean (M)? Or rather, what frame/s do they evoke? Before answering this question, it is necessary to zoom in on the form (F) 'metaphorâ' more closely and study Aristotle's definition of it. 


\subsection{Aristotle's definition of metaphorá}

The conceptual foundation i.e. the source frame of Aristotle's definition of metaphor is found in the construction of the Greek form, metaphorá. In what follows, it is important to keep in mind that Aristotle's definition of metaphorá is itself a metaphor. The form metaphorá is a nominalization of the verb form metaphérein and evokes the same frame. A nominalized verb represents an activity and all the participants as a snapshot, as opposed to a moving picture. The nominalized form could be a snapshot of the process in whole or at any point of the moving picture. Langacker (1991) calls nominalization the "conceptual reification" of an activity. It is much easier to reconstruct a frame from studying the uses of the verbal form in context. The Greek verb metaphérein (to transfer) evokes a frame that will be very familiar to an English speaker. A concrete example is found in Plato's Timaeus (Tim. 73c). God was interested in constructing a human skeleton. As a part of God's involvement in this endeavor, he formed the bones by transferring (metaphérein) a mixture of earth and marrow back and forth between fire and water several times. One engages with one's body in this activity regularly: in a person's effort to create something, she transfers an item from one location and puts it in another.

Aristotle's seemingly simple definition of metaphor in Poetics - metaphorà dé estin onómatos allotriou epiphorà 'metaphor is the epiphor of another (thing)'s name' (1457b6) - exhibits in full the source frame. In the definition, parts of the frame structure are implicit, others explicit. Implicit are the locations of the transfer, that there is an agent that does the transferring and the concern that initiated the transfer. Though these parts of the frame are not explicitly stated as part of the definition, a speaker of the language would understand that location, agent and concern are present in the background. Aristotle does, indeed, mention these in other parts of Poetics and Rhetoric. ${ }^{38}$ What Aristotle does make explicit is the end result of the process. To do this he uses another nominalization, epiphorá 'a placing upon', to identify this result. As regards the term epiphora, Aristotle had in mind the sense 'assigning of words'. His teacher Plato had used the term epiphorá in this very way (Plat. Stat.307b). Aristotle also used the verb form epiphérein in this sense: 'to assign a word to' (Arist. Rh.1408a11). Thus, as Aristotle defines it, “metaphor is a (re)-assigning of another (thing)'s name”. This process may be simply illustrated like this: suppose one is at a party and everyone has a name tag. The host, concerned with creating a

38 Aristotle's further discussion of this definition explicitly mentions the possible types of DomaIN involved in the transfer: genos to eidos, eidos to genos, eidos to eidos or transference based on analogy (Po. 1457b7-9). The concern that initiates the transfer is discussed as persuasion in Rhetoric, "Let rhetoric be, then, the capacity of considering every possible device of persuasion [éstō dè hē rhētorikè dúnamis perì hékaston toû theōrêsai tò endekhómenon pithanón]" (Arist. Rh. 1355b26), and imitation in Poetics, "All [forms of poetry] add up to being an imitation [pâsai tugkhánousin oûsai miméseis tò súnolon]" (Arist. Po. 1447a15). Of course, the agent in Poetics or Rhetoric would be the poet or rhetorician. 
mood of merriment, takes the name tag off of John, brings it over (metaphorá) and places it on (epiphorá) Mary.

From this definition of metaphor, two things become evident: (1) as Lloyd (1996) noticed, Aristotle's very use of the term metaphorá is itself a metaphor, i.e., a transfer of the term "from its own strict application, which would be to the transport of physical objects". Aristotle transferred the term metaphorá from its use in the physical domain to its use in the abstract domain of lógos. However, as I attempted to make clear above, it is not just the term metaphorá that is tranferred, but the entire source frame that the form (F) metaphorá evokes; (2) Aristotle identifies another type of word use: the allotrion. This yields then, three types of word use that define the léxis of everyday lógos: the kúrion, the oikeîn and the allótrion. From Aristotle's definition of metaphor, it is clear that an allótrion ónoma (a word that belongs to another) is a word used metaphorically. The next section will deal specifically with the meaning of kúrion and oikeîon.

\subsection{Aristotle's metaphor of the léxis of everyday lógos}

Lloyd (1996) states: "The basic vocabulary for describing what metaphorá is is thus full not just of what we might term the 'metaphorical' but of what Aristotle himself treats as metaphorá". According to Lloyd, in addition to the term metaphorá itself, this "basic vocabulary" includes the adjectives kúrion, oikeîon and allótrion. The larger conceptual metaphor, of which the term metaphorá is only a part, I identify as the metaphor of 'THE LEXIS OF EVERYDAY LOGOS'. But this raises the question: What do kúrion and oikeîon mean in this context?

In the context of lógos, kúrion is usually translated as 'ordinary' (O’Rourke, 2005) or 'strict' (Crittenden, 2003; Lloyd, 1996). Oikeîon is translated as 'regular' (O’Rourke, 2005), 'appropriate’' (Lloyd, 1996), 'ordinary’ (Crittenden, 2003). Wood (2015) and Kirby (1997) claim that the two are synonyms. Lloyd (1996) and Crittenden (2003) acknowledge that these three adjectives are used metaphorically, but their translations do not show any change in interpretation as a result. One can readily see that the usual translations of kúrion and oikeîon, and allótrion, hide what Aristotle means, rather than being helpful. The reason for this lack of transparency is that the translations do not evoke a comprehensible source frame i.e. the conceptual foundation, from which these adjectives gain meaning in the target frame of the lexis of everyday lógos. (The léxis of everyday lógos is itself a part of the larger domain of lógos). So, it becomes the philologist's task to reconstruct this ancient Greek semantic frame. How would one proceed? Once again constructions are helpful.

Sullivan (2013: 5.3 and 2) has researched the roles that frames and syntactic constructions play in metaphorical language in English. She noticed that when a predicating adjective/noun construction is used in a metaphor, the predicate adjective evokes the source domain and the noun evokes the target domain. This applies to ancient Greek as well. The adjectives kúrion, oikeîon and allótrion, used as 
an ensemble, evoke the source frame of oikein 'dwelling' in the city-state/ household (see Lloyd, 1996). The noun ónoma 'word' evokes the target frame, lógos.

\subsubsection{The source frame: 'DWELLING IN A HOUSEHOLD'}

Aristotle saw dwelling in the city-state as the natural end of a series of human partnerships (koinoníai). By natural end, he means that which has grown to full maturity. Just as a rose bush has reached its natural end in the blossoming rose, so also human partnerships reach their natural end in the blossoming city-state. Every partnership is composed of the ruler and the ruled. A city-state is a partnership composed of, and is the natural outgrowth of, a number of households. The household is the smallest partnership (Arist. Pol. 1252b29ff). The structure of all partnerships is composed of: (1) the kúrios as governor, (2) the oikeîos as one who is governed in and a member of the partnership, (3) the allótrion as one who, once having been a member (oikeîos) in another partnership and under the rule of another kúrios, is presently part of the partnership. Aristotle says that one may find in the structure of the household a model (parádeigma) of the city-state (Arist. EN 1160b22-35). Thus, to simplify, I will use the model of the ancient Greek household in the discussion which follows.

The orator Isaeus provides us with a wealth of information about dwelling in the Athenian household. He lived and worked in Athens at roughly the same time as Aristotle. He was engaged in writing speeches for those who were defending themselves in disputes of inheritance. Eleven of his speeches still survive. The speech De Apollodoro gives us a glimpse of this kúrios, oikeîos, allótrios structure in the household. Thrasyllus, in arguing why he is the legitimate heir of the household of Apollodorus, says,

For [Apollodorus] knew well how I had behaved for my father and mother, knowing, as well, the care I had for the members (oikeîoi) and how I managed my personal affairs . . . so it was not in ignorance, but with clear knowledge, that he appointed me governor (kúrios) of his household (lit. 'of his things', tôn hautoû). Moreover, I am not an allótrios but a nephew”. (Isaeus De Apoll. 34.2-35.7)

\subsubsection{The target frame: 'THE LEXIS OF EVERYDAY LOGOS'}

Using this outline of the source frame as foundation, we are in a position to ask how it helps a reader understand what Aristotle means in using kúrion, oikeîon and allotrion in the target frame. A basic structure is established in the mapping of the roles played by the kúrios, the oikeîoi and the allótrios in the source frame 'DWELLING IN THE HOUSEHOLD' onto the target frame 'THE LEXIS OF EVERYDAY LOGOS'. The kúrion ónoma in some way rules or governs the 'household'. The kúrios is the 'source' 
(arkhê).$^{39}$ The oikeîon ónoma in some way belongs to the 'household' and is governed by the kúrion ónoma. The allótrion ónoma creates otherness in the 'household' by being transferred from another 'household'. This, then, leads to the next question: in the target frame, what is this metaphorical 'household'? The answer is found in what, according to Aristotle, words (onómata) signify, namely the ousía, the prâgma, the hóros, and the eîdos.

\subsection{The metaphorical household}

The question of what the Greek terms ousía, prâgma, hóros, and eîdos mean loom large in Aristotle's philosophical discourse. Be that as it may, for the purpose of this study, I will narrow the focus to what these important ideas mean in relationship to the term ónoma (word). The three concepts ousía, prâgma, and eîdos overlap in their role as the metaphorical household and hóros defines it. This section deals with the prâgma and the hóros. Ousía and eîdos will appear in section 8.6.1, where the kúrion is defined.

In relation to prâgmata Aristotle presents words (onómata) as functioning in two ways: (1) as a 'symbol' of the prâgma (súmbolon); (2) as encapsulating the 'definition' (hóros) of the prâgma. The noun prâgma is a nominalization of the verb prássein. Prássein has a general meaning, 'to be involved with the affairs or concerns of living'. Thus, the prágmata are snapshots of involvements in living, or the accomplishments of whatever is of concern for living.

Aristotle's account of the function of words is largely found in his treatises Peri Ermēneías 'Concerning Expression', more commonly entitled in the Latin translation De Interpretatione, ${ }^{40}$ and in the Sophistical Refutations. In De Interpretatione he sets a semiotic triangle: humans use words as symbols to signify the 'thought processes' (pathếmata) of the 'mind' (psukhê) (Chriti, 2018). The thoughts are 'likenesses' (homoiômata) of the prágmata. (Arist. De Interp. 16a 3-8). So, the 'word' signifies the prâgma via the páthèma. And, as he notes in the Sophistical Refutations, 'Since it is not possible to carry on a conversation by bringing in the actual prágmata, we use words (onomata) as symbols' (Arist. SE 165a 6-7). That is, since it is usually impossible to have the actual events occurring as we speak about them (as a sportscaster does),

39 Note that as pointed out in the Pol. the kurios of an oikos is the arkhé (Arist. Pol. 1278b37). Aristotle also says that the dunamis ('power' or 'potential') of an arkhế is a kuria (of something) (Arist. Pol.1300b5-12).

40 Hermēneía, which I have translated as 'expression', usually titled by the misleading Latin translation De Interpretatione, is used here in the same sense as Aristotle used it in Poetics 1450b14, "Lexis is the hermeneia "expression” [of logos] through the use of onomata 'words' [légō dé, hốsper próteron eírètai, léxin eînai tèn dià tês onomasías hehermēneían]”. 
humans use words to signify events (prâgmata) as conceived in the mind. ${ }^{41}$ As symbols, words (onómata) give us the ability to talk about the affairs or concerns of living, the prâgmata - past, present, and future.

Aristotle also identifies an intrinsic relationship between words (onómata) and hóroi (plural of hóros) in Topics and Posterior Analytics (cf. Deslauriers, 2007; Devereux, 1988; Lewis, 2013). This also introduces another term, hóros, that he transferred from the source frame of 'DWELLING IN A HOUSEHOLD' into the domain of logos. In the Greek world of Aristotle's time, there were stones called horoi, used in marking boundaries. The hóroi were an important part of one's embodied experience of dwelling in the household. They 'defined' or 'gave boundaries to', not only the physical space of a household (or a city-state), but also the people and property within, i.e., the ousia, as assigned to a particular governor (kúrios). These boundary markers were assigned to mark a space as private, public, sacred, leased or to indicate a lien on a piece of property (Fine, 1951; Ober, 1995). Aristotle used the term horros in the domain of logos to mean those (metaphorical) stones that mark the boundaries of a specific prâgma. "A boundary stone (hóros)", as Aristotle states, "is a statement (lógos) that makes clear the essence of a prâgma" (Arist. Topica 153a15-16). Aristotle uses the term lógos here to mean a concept that has been brought to expression in the form of a statement. He also wrote that the "horismos (a type of horos) is a statement (lógos) of what a word (ónoma) signifies”. As an example, he points out that the term 'triangle' (trígōnon), signifies, in a single word, the definition (hóros) of "triangle" (Arist. A.Po. 93b 29-32). ${ }^{42}$

So, a single word signifies the prâgma doubly. As a symbol, it evokes the concept of a prâgma and, at the same time, encapsulates the definition (hóros), i.e., the statement (lógos) of what a particular prâgma is. Just as these boundary stones (hóroi) divided Greece into several city-states and the city-states into several households, so also words (onómata) symbolize the conceptual divisions of the world into prâgmata. Thus, 'household' from the source frame maps onto the prâgma in the target frame and places it within the inferential structure as it pertains to word use.

This, now, leads to the how questions: How does the kúrion ónoma "govern" the metaphorical household, i.e., the concept of the prâgma? How is the oikeîon ónoma a "member" of it? And how does the allótrion ónoma "create something different" within it?

41 De Rijk (2002) presents a similar view of the prâgma: “To [Aristotle], the word's meaning is purposely ambivalent, its focal meaning ('state of affairs conceived of') happily oscillating between referring to 'a real state of affairs', which happens to be conceived of and 'a conceived state of affairs qua conceived of (irrespective of its being, or not being, the case)'”.

42 The term horismos is derived from horos and Aristotle uses it with little difference from horos. 


\subsubsection{Kúrion ónoma}

In what manner does the kúrion ónoma, as a symbol, "govern" the concept of the prâgma? Who "appoints" any single word as "governor"? ${ }^{43}$ Aristotle divides the kúrion use of a word into three parts: (1) "conventional" (katà sunthếkēn); (2) "the clearest” in reference, (saphestâtē); (3) in contrast to a metaphor. In Poetics Aristotle gives his definition (horos) of the kúrion ónoma:

The definition of the 'governing [word]' (kúrion) is [a word] which people in one location use [to refer to something]. [This same word] is an 'unfamiliar word' (glôtta) to those in another location. Thus, it is clear that both the unfamiliar word and the governing word [can] be the same in the power [of signification] ${ }^{44}$ but this same word [form] in one location is governing, and in another location unfamiliar. For example, for those who inhabit Cyprus the word 'spear' (sígunon) is the governing word, but for us (in Athens) it is an unfamiliar word (Arist. Po.1457b3).

Aristotle is speaking about those who dwell in a particular city-state or region choosing a word form to signify a prâgma. As his example shows, when conversing about spears in the region of Cyprus, the Cypriots have chosen the word form sigunon, to signify 'spear'. Sigunon is not a word used in Athens. There, it is an unfamiliar word. But in the city-state of Athens, one could use hakóntion to signify a 'spear'; hakontion is an unfamiliar word in Cyprus. Thus, words are "appointed" as governing words by those who dwell in a city-state to signify a given prâgma. It is interesting to note that Isocrates 346-338 BCE, an orator in Athens, calls this use of governing words 'the words of the city-state' (politikà onómata) (Isoc. Ev. 9.10). Aristotle and Isocrates, in their definitions, indicate that members of a city-state "appoint" the governing words. Words are 'conventional' (katà sunthêkên), (Arist. De Interp. 16a 19ff). It is because each governing word (kúrion) is "appointed" to signify a particular prâgma by those dwelling in a city-state, that Aristotle declares, "The clearest [reference], therefore, is when using governing words (saphestátē mèn oûn estin hē ek tôn kuriōn onomátōn)" (Arist. Po. 1458a 18-19). ${ }^{45}$ So, it appears as though the governing word (kúrion) has a single unambiguous signification, and is perhaps equivalent to what we mean by "the literal" sense of a word. This is not the case. There is no literal/metaphorical distinction in Aristotle's thought. There is only the distinction between the governing

43 Recall, that one of the inferences, potentially transferred, is that a kurios is appointed. As Thrasyllus argued, [Apollodorus] appointed me kurios of his [oikos]. See 2.4.

44 An alternate translation could be 'able to be the same thing' i.e., be the same in reference.

45 See also Arist. Rh. 1404b 5-6, "Of the onomata and rhêmata the kuria [onomata] create clearness [tôn d' onomátōn kaì rhrhēmátōn saphê mèn poieî tà kúriatôn d' onomátōn kaì rhrhēmátōn saphê mèn poieî tà kúria]". It should be mentioned, at this point, that Aristotle used the term onoma to specifically refer to a noun as opposed to a rhêma, a verb. However, onomata is also a general way of referring to all types of words. 
and the metaphorical use of words. The governing word is itself polysemous. How is this so?

The general phrase Aristotle uses at the outset of a discussion of the meaning of a word is "[a word] is said in many ways (légetai pollakhôs) (Arist. Meta. 1046a4-5). This means, a word has many potential senses. Two ways of expressing potential senses are contrasted as the governing use of a word (kúrion) and the metaphorical use (allótrion). In Topics he expresses it this way, légetai . . . kuríōs è katà metaphoràn 'expressing [a word] either in the governing or the metaphorical manner' (Arist. Top. 158b10-12). Kurîôs ('governingly') is the adverbial form of the adjective kúrios; legetai kuriôs is another way of expressing that one is using a governing word.

According to Aristotle, using a word in the governing manner evokes what he calls pròs hén meaning, literally translated 'towards one thing' (Arist. Meta. 1061a11). The pròs hén use of a word has been dubbed "focal meaning" or "core-dependent homonymy" in recent Aristotle scholarship. Beere (2009) describes focal meaning this way, "Aristotle thinks that there is a family of connected usages of a term, that cluster around a single, primary usage to which all others make reference”. Or, in line with the metaphor, there is a 'household' in which the 'governor' (kúrios) rules a 'family' of senses. These [sub]senses are dependent on and derive from the governing (kúrios) sense. If one is speaking "governingly", the single form of a word can evoke any one of these senses, depending on context. Aristotle says that this 'family' is formed by 'belonging to the same eidos' (pròs tò autò eîdos) (e.g., Arist. Meta. 1046a9). He also refers to this 'household' in which the ambiguous 'family' of senses resides as the ousia, stating, "One must not overlook the fact that at times it escapes one's notice if a word (ónoma) signifies the ousia as a composite whole or just it's actuality and form ... thus, [the ousia] is not being signified (legomenon) by means of a single definition (lógos), but by means of focal meaning (pros hen)" (Arist. Meta. 1043a 29-38). So, eid os and ousia along with prâgma are three ways to express what the governing use of a word signifies: the metaphorical 'household'. ${ }^{46}$ In this household there are a 'family' of senses; however, Aristotle does not consider any of these senses to be a metaphor; a metaphor is an allótrion. It belongs to another household.

Aristotle's analysis of dúnamis, which I translate as 'power', is a clear example of the contrast between focal meaning (kúrion) and metaphor and touches on the important topic of "likeness" which will be addressed in detail in 8.7 below (Arist. Meta. 1019a 15-1020a 6, 1046a 4-b 7). In Aristotle's account, the governing (focal) use of the word dúnamis includes all the senses that somehow are the 'source' (arkhê) of movement and change (Meta. 1019a 15-16). All these senses belong to this same eidos, i.e., household (Arist. Meta.1046a9). But, he notes, there is one use of the word dúnamis that does not belong to this 'household': its use in geometry. In Metaphysics

46 In fact, Aristotle identifies the eidos as the ousia, stating "I define eidos as the essence and the primary ousia [eîdos dè légō tò tí ênên eînai hehekástou kaì tền prốtēn ousía]" (Arist. Meta. 1032b1). 
there are two discussions about the meaning of the word dúnamis. In both discussions he talks about the use of dúnamis in geometry. In Delta he calls it 'metaphorical', katà metaphoràn dè hē en geōmetríai 'in geometry [dúnamis] is used metaphorically' (1019b33), and in Theta he calls the use 'according to some likeness', homoiótéti tini légontai katháper en geōmetríai '[dúnamis] is used according to some likeness, just as [it is used] in geometry' (1046a7-8). Thus, there are three ways of referring to the metaphorical use of a word: (1) metaphorá, (2) allótrion, (3) homoiotês ('likeness'). When used 'according to likeness' in geometry, 'power' (dúnamis) metaphorically refers to the line segment $A B$ of any square. The 'power' of this line determines the size of any square, but it is not the source of movement or change. The size of a square remains static, subject to this 'power', i.e., the length of line segment $A B$. This metaphorical use of the term dúnamis will be expanded in 8.7.

\subsubsection{Oikeîon ónoma}

What would it mean to be an oikeîon ónoma? In what manner is the oikeîon ónoma a "member of" the 'household'? Aristotle never directly defines the 'member word' (oikeîon ónoma); however, there are two texts that give us a glimpse at what it might mean. These texts strongly suggest that a 'member word' (oikeîon) signifies an attribute or a part of a whole 'household' (ousia-eidos-prâgma) as established by the governing word. This is similar to the concept of profile and base as introduced by Langacker (1987; 1991). The governing word identifies the base, e.g., wheel, and member words (oikeia) profile some part of the wheel, e.g., hub or spoke.

The first of these two texts under consideration is in Poetics. In it Aristotle presents the example of the metaphor of the word phiále 'offering cup'. The two poets Anaxandrides and Antiphanes, contemporaries of Aristotle, used this metaphor, so it is likely that it was familiar to his audience. The 'offering cup', was one of the attributes of Dionysus. In Aristotle's interpretation, both these poets used the word phiale metaphorically to signify the aspís 'shield', an attribute of Ares (Arist. Po. 1457b20-33). ${ }^{47}$ Aristotle continues his discussion by pointing out that not only does one use a member word (oikeîon) in a metaphor, one can make it more interesting 'by removing an attribute from the member words [themselves]' (apophêsai tôn oikeíōn ti), like calling the shield not just an offering cup but a 'wineless offering cup (áoinon phialê)' (Arist. Po. 1457b31-33). This would be equivalent to calling the hub of a wheel a 'spokeless hub'. The second text is found in Rhetoric. Here, Aristotle advises the orator 'to carry out a metaphor by [use of] the member words' (apò oikeíōn) (Arist. Rh. 1412a11-12).

47 He also discusses this example of Dionysus and Ares in $R h .1407 a 15-13 ; R h .1412 b 33-1413 a 3$. 
It seems clear that Aristotle sees in metaphor the transfer of a member word (oikeîon) from one 'household' to another 'household'. Once transferred, the member word (oikeîon) becomes a word belonging to another (allótrion) 'household' and is (re)-assigned (epiphora) as a signifier of some attribute in the new 'household'. This (re)-assignment of a member word is not random, but as Aristotle indicates, is based on 'likeness'.

\subsection{According to likeness}

In Topics, Aristotle states "For metaphor makes that which is signified in some manner evident by means of likeness, for everyone who uses words metaphorically does so based on some sort of likeness (hè mèn gàr metaphorà poieî pōs gnốrimon tò sēmainómenon dià tèn homoiótēta [pántes gàr hoi metaphérontes katá tina homoiótēta metaphérousin])". (Arist. Top.140a8-11). In this section, I broach the question of what Aristotle meant by homoiotês 'likeness' as regards metaphor. In the discussions of metaphor in Poetics and Rhetoric, Aristotle appears to base metaphor on an objective, literal, and preexisting similarity of two images in a symmetrical relationship. Dancygier \& Sweetser (2014) call this an "image metaphor", explaining that, "this [type of] metaphor doesn't seem to have significant structure mapped beyond the image similarity" e.g., a women's waist being referred to as an hourglass. Aristotle's example of the metaphor of the offering cup (phialê) (2.5.3) is, in fact, an image metaphor. The offering cup is a bowl-shaped object that looks like a shield. Aristotle even states that there is a symmetrical relationship between the two images, noting that one could equally call the offering cup of Dionysus a shield (Arist. Po. 1457b20). Based on such discussions in Poetics and Rhetoric, image metaphor, often called the "traditional view" of metaphor, wherein there is an objective, literal, pre-existing, symmetrical likeness between images (Kövecses, 2010), is popularly ascribed to Aristotle.

However, the discussions in these texts are not the whole story. Based on an account in the Eudemian Ethics, I will argue that Aristotle does recognize a type of metaphor in which likenesses are asymmetrical correlations in experience that reflect nonobjective, nonliteral, and non-pre-existing similarities.

As discussed in 8.6.1, Aristotle mentioned that in geometry the term dúnamis is used according to likeness/metaphorically. This use was in opposition to the governing (kúrion) use of dúnamis. The reason he calls its use in geometry a metaphor, is because the term is being transferred from the eidos of the physical perceptible domain that has movement and change, to the eidos of the noetic domain where no movement or 
change occurs. Geometry, as a part of mathematics, is in the noetic domain. ${ }^{48}$ But what 'likeness' is there between dúnamis used in the physical 'household' of movement and change and dúnamis used in the mathematical 'household' where no movement takes place (Arist. Meta.1046a7-8; 1019b33)?

The answer is found in Aristotle's discussion of necessity in Eudemian Ethics. Recall that Aristotle says that a power (dúnamis) is the source (arkhê) of movement (kínēsis) (2.5.2). According to Aristotle, in order for there to be movement (kinēsis) there must be a governor (kúrion) to govern that movement. An example he gives is the obvious fact that a human, by necessity, gives birth to humans. The human ousia is the source (arkhê), the explanation (aítion) and governor (kúrion: another metaphorical use of the term) of movement (kinēsis). From a human source only a human will grow and develop into a human. This is necessarily the case. But what about the use of the term arkhế in mathematics? In mathematics, a triangle is a source (arkhê), and explanation (aítion), but since there is no movement, it is not a governor (kúrion). So, Aristotle says, in mathematics the term archê, "is being obviously used according to likeness ([légetaí ge kath' homoiótēta])” (Arist. EE1222b24-25), i.e., metaphorically. The idea is this: as in the perceptible domain a source (arkhế) is an explanation (aition) of things changing into and out of a given form, i.e., the reason why "things come into and go out of existence", so in the noetic domain a source (arkhế) is an explanation (aition) of why things don't change, i.e., why "they exist in the manner that they do" (EE 1222b30-31). So, he concludes, a triangle is metaphorically a source (arkhê) in the sense that it is an explanation (aítion) of why the other geometrical figures do not by necessity change (EE 1222b40-41). Therefore, since power (dúnamis) is a source (arkhê), the term dúnamis in geometry metaphorically (according to likeness) refers to a line segment that had the power (dúnamis) to be the source (arkhế) for the explanation (aition) of why any square was and remained a certain size; the size of any square is always and by necessity based on the size of the line segment $A B$ (Beere, 2009; Heidegger, 1995; Mugler, 1958). So, based on his account of dúnamis in the Metaphysics and arkhé in Eudemian Ethics, Aristotle demonstrates that terms mathematicians used are metaphorically based on experience in the physical world. These terms arkhé, dúnamis and aítion are used "according to likeness" based upon asymmetrical correlations in experience "that reflect nonobjective, nonliteral, and non-pre-existing similarities”.

In the explanation of the meaning of the term homoiotês, Aristotle is recognizing that some inferences are carried over in the metaphor but others are not. He points to a constraint placed on what the terms arkhế, dúnamis and aítion mean in mathematics. The constraint, lack of movement and so lack of a governor (kúrion), is found in the target frame itself. The lack of a governor in the domain of mathematics constrains

48 "I mean noetic like [branches] of mathematics [légō dè noētoùs mèn hoîon toùs mathēmatikoús]" (Arist. Met. 1036a3). 
what these terms metaphorically mean. The fact that Aristotle recognizes a likeness between the use of these terms in the physical and the noetic domains strongly suggests that he saw an abstract generic conceptual structure that is shared by both the source frame and the target frame in this metaphor.

\subsection{Conclusion}

Using the embodied basis of constructions as an aid in a re-reading of the ancient Greek of Aristotle's texts, I have set out to accomplish two objectives: (1) to present an example of the analytic potential of cognitive linguistics for the interpretation of ancient texts; (2) to allow cognitive linguistics to answer the question of "what" Aristotle represents to it, in its own terms. To obtain these objectives, I presented a reassessment of Aristotle's theory of metaphor. Its aim was to bring into question the traditional view of Aristotle which prevails among both those in Aristotle studies and those in the cognitive sciences. Traditionally Aristotle is assumed to have believed that: (1) metaphor is literary device on the level of language and is not included in everyday language use; (2) one should not use metaphor as a part of philosophical discourse; (3) there is a literal/metaphorical dichotomy; (4) likeness in metaphor is only based on a correspondence of literal properties between things in the concrete perceptible world.

This reassessment was based in the relationship between human embodied involvement in the concrete world and linguistic meaning. Linguistic meaning (M) is expressed in the form ( $\mathrm{F}$ ) of grammatical constructions which can be of any size. Once learned, an uttered construction evokes an idealized cognitive model of our participation in cultural events called frames. Metaphor is based on the transference (mapping) of constructions between a source frame and a target frame and comes in two forms: One is conceptual metaphor which is the asymmetrical mapping of the terminology and inferential structure from a source that is more intersubjectively available to a source that is less intersubjectively available. These are respectively called the source frame and the target frame. Conceptual metaphor gives us the ability to reason and communicate about experiences that are less intersubjectively available. The other is image metaphor which is the symmetrical transference of sensory experience that does not necessarily involve the transference of inference.

Assuming this model of meaning, I proceeded to reassess Aristotle's theory of metaphor. The question of whether or not Aristotle recognized metaphor as a part of everyday language use is addressed in his discussion in Rhetoric. I argued (section 8.3), based on $R h$.1404b32-34, that not only did Aristotle include metaphor in the everyday use of language, he sanctioned its use by the rhetorician on its use in everyday language. From this text, I was also able to find the terminology that Aristotle used in his categorization of word use in everyday language: the kúrion, the oikeîon and 
metaphorá. Based on this terminology, I set out to gain a broader understanding of his theory of metaphor.

The next step (section 8.4) was to examine Aristotle's definition of metaphor in Poetics 1457b6. From this text, I concluded that Aristotle's use of the term metaphorá in the context of lógos is itself a metaphor, that is, a transference of the term from the source frame of the moving of concrete objects from one physical space to another to the target frame of logos. It was also from this text that it became clear that a metaphor is also called an allótrion.

At this point it became clear that if the term metaphorá is itself used metaphorically, then perhaps other terms he used in his writings about word use are used metaphorically as well. With the insight from Karen Sullivan that in predicate adjectives/noun constructions the adjective determines the source frame and the noun determines the target frame, I looked for a context in which the terms kúrion, oikeîn and allótrion were used as an ensemble in order to determine the probable source frame (section 8.5) which I concluded is dwelling in the city-state and household. Once the source frame was in place (section 8.5.1), I was able to examine what these terms meant in the context of logos based upon their use in the intersubjectively accessible (embodied) experience of dwelling in the Greek household. It also became clear the Aristotle's theory of metaphor is a part of a larger conceptual metaphor of word use.

Based on the mappings of this conceptual metaphor (see Figure 1), I concluded that: (section 8.6.1) as the kúrion is the governing element in a household, so a kúrion word is a "governing" word that is assigned by those in a city-state to refer to a given prâgma in whole. Based on the examination of Aristotle's discussions of meaning in texts outside of the Poetics and Rhetoric, I argued that there is no literal/metaphorical dichotomy in his philosophy because the kúrion is a polysemous family of senses that all belong to the same 'household'; each individual sense derives from one central sense; this is what is known as focal meaning. Aristotle did not consider these derived senses to be a metaphor. A metaphor is an allotrion, that is, a word that is transferred from another 'household' for re-assignment. This re-assignment is based on likeness. It also became obvious in this section, that Aristotle did in fact use metaphor in his philosophical discourse. I pointed out that the philosophically central terms ousia and horos are both transferred from their use in the source frame of dwelling in the household to their uses in various discussions throughout Aristotle's philosophy. An oikeîn (section 8.6.2) is a word that refers to some attribute or part of the whole, once established by the kúrion. Aristotle suggests that metaphors are best carried out via the oikeîon. In section 8.7, I argued that Aristotle saw likeness in metaphor as based not only on objective, literal, pre-existing, symmetrical likenesses between images exclusively, but also on asymmetrical correlations in experience that reflect nonobjective, nonliteral, and non-pre-existing similarities.

I conclude, then, that the two objectives I have set out to attain have been reached: (1) The analytical potential of cognitive linguistics has been demonstrated 
to be useful for doing a careful reading of ancient texts. Its use in this reassessment introduces a new view to our understanding of the possible conceptual foundations of Aristotle's philosophy, provides new avenues of inquiry and raises many questions; (2) "what" Aristotle is to cognitive linguistics has been answered in its own terms. I would say, based on this reassessment, that Aristotle has in many ways anticipated the cognitive turn in the philosophy of human language. His theory of metaphor has many similarities to conceptual metaphor. But even more interesting are some of the differences, e.g., he sees in polysemy word senses that cluster around and derive from a central sense that are not metaphorical. With more research into Aristotle's discussions of language and meaning along these lines we can gain deeper insights into the mysteries of meaning.

\section{Bibliography}

Beere, J. (2009). Doing and Being: An Interpretation fo Aristotl's Metaphysics Theta. Oxford: Oxford University Press.

Chriti, M. (2018). Aristotle as a Name-giver: The Cognitive Aspect of his Theory and Practice. https:// chs.harvard.edu/CHS/article/display/1304? menuld=18

Crittenden, P. (2003). Philosophy and Metaphor: The Philosopher's Ambivalence. Literature and Aesthetics, 13 (1), 27-42.

Dancygier, B. \& Sweetser, E. (2014). Figurative Language. Cambridge: Cambridge University Press.

de Rijk, L. M. (2002). Aristotle: Semantics and Ontology. Volume I: General Introduction. The Works on Logic. Leiden: Brill.

Deslauriers, M. (2007). Aristotle on Definition. Leiden: Brill.

Devereux, D. D. (1988). Essence, Existence, and Nominal Definition in Aristotle's “Posterior Analytics" II 8-10. Phronesis, 33 (2), 133-154.

Fine, J. V. (1951). Horoi: Studies in Mortgage, Real Security, and Land Tenure in Ancient Athens. Hesperia Supplements, 9.

Geeraerts, D. (2006). Words and Other Wonders: Papers on Lexical and Semantic Topics. Berlin: Mouton de Gruyter.

Goldberg, A. (2010). Verbs, constructions, and semantic frames. In M. Hovav, E. Doron \& I. Sichel (Eds), Syntax, Lexical Semantics, and Event Structure. Oxford: Oxford University Press.

Goldberg, A. (2013). Constructionist Approaches. In T. H. Trousdale (Ed), The Oxford Handbook of Construction Grammar. Oxford: Oxford University Press.

Heidegger, M. (1995). Aristotle's Metaphysics TH 1-3: On the Essence and Actuality of Force (W. Brogan, \& P. Warnek, Trans). Bloomington: Indiana University Press.

Rosch 1999 = Institute, P. (1999, October 15). Primary Knowing: When Perception Happens from the Whole Field. Interview with Professor Eleanor Rosch. Retrieved April 22, 2016, from Presencing Institute: https://www.presencing.com/dol/rosch\#one

Isaeus (1962). Isaeus with and English translation by Edward Seymour Forster. Cambridge, MA: Harvard University Press.

Kirby, J. T. (1997). Aristotle on Metaphor. The American Journal of Philology, 118 (4), 517-554.

Kövecses, Z. (2010). Metaphor: A Practical Introduction (2nd ed). Oxford: Oxford University Press.

Lakoff, G. (1987). Women, Fire and Dangerous Things: What Categories Reveal about the Mind.

Chicago: The University of Chicago Press. 
Lakoff, G. \& Johnson, M. (1999). Philosophy in the Flesh: The Embodied Mind and its Challenge to Western Thought. New York: Basic Books.

Langacker, R. (1987). Foundations of Cognitive Grammar. Vol. 1: Theoretical Prerequisites. Stanford: Stanford University Press.

Langacker, R. (1991). The Foundations of Cognitive Grammar. Vol. 2: Descriptive application. Stanford: Stanford University Press.

Lewis, F. A. (2013). How Aristotle gets by in Metaphysics Zeta. Oxford: Oxford University Press.

Lloyd, G. E. (1996). Aristotelian Investigations. Cambridge: Cambridge University Press.

Marcos, A. (1997). The Tension Between Aristotle's Theories and Uses of Metaphor. Studies in History and Philosophy of Science, 28 (1), 123-139.

Modrak, D. (2001). Aristotle's Theory of Language and Meaning. Cambridge: Cambridge University Press.

Mugler, C. (1958). Dictionnaire historique de la terminologie géométrique des Grec. (Vol. 1). Paris: Klincksieck.

O'Rourke, F. (2005). Aristotle and the Metaphysics of Metaphor. In J. C. Gurtler (Ed), Proceedings of the Boston Area Colloquium in Ancient Philosophy, 155-177.

Ober, J. (1995). Greek Horoi: Artifactual Texts and the Contingency fo Meaning. In D. Small (Ed), Methods in the Mediterranean: Historical and Archaeological Views on Texts and Archaeology. Leiden: Brill.

Sullivan, K. (2013). Frames and Constructions in Metaphoric Language. Amsterdam \& Philadelphia: John Benjamins.

Swiggers, P. (1984). Cognitive Aspects of Aristotle's Theory of Metaphor. Glotta, 40-45.

Taylor, J. (2003). Linguistic Categorization: Protoypes in Linguistic Theory (3rd ed). Oxford: Clarendon Press.

Trigger, B. G. (1996). A History of Archaeological Thought (2nd ed). Cambridge: Cambridge University Press.

Wood, M. S. (2015). Aristotle and the Question of Metaphor. Ottawa: University of Ottawa.

Ziem, A. (2014). Frames of Understanding in Text and Discourse: Theoretical foundations and descriptive applications. Amsterdam: John Benjamins. 